Original Research Article

\title{
Side effect profile of hepatitis $C$ treatment with peginterferon alpha-2b and ribavarin
}

\author{
Syed Mubashir ${ }^{1}$, Irfan Gul ${ }^{2 *}$, Abid Rasool ${ }^{1}$, Shujat Gul ${ }^{2}$, \\ G. M. Gulzar ${ }^{1}$, Muzamil Ahmad Wani ${ }^{2}$
}

${ }^{1}$ Department of Medicine, SKIMS Soura, Srinagar, Kashmir, India

${ }^{2}$ Department of Medicine, Government Medical College, Srinagar, India

Received: 13 May 2017

Revised: 01 June 2017

Accepted: 02 June 2017

*Correspondence to:

Dr. Irfan Gul,

Email: irfanbeigh33@gmail.com

Copyright: () the author(s), publisher and licensee Medip Academy. This is an openaccess article distributed under the terms of the Creative Commons Attribution NonCommercial License, which permits unrestricted noncommercial use, distribution, and reproduction in any medium, provided the original work is properly cited.

\begin{abstract}
Background: The major types of side effects include fatigue, influenza-like symptoms, gastrointestinal disturbances, neuropsychiatric symptoms and hematologic abnormalities. These side effects may be treatment limiting and require dose reduction or drug discontinuation objectives of the study was to assess the side effect profile of hepatitis $\mathrm{C}$ treatment (peginterferon alpha- $2 \mathrm{~b}$ and ribavarin) in Kashmiri patients attending the Department of Gastroenterology skims.

Methods: In this study, all consecutive patients of hepatitis $\mathrm{C}$ infection on peginterfron and ribavarin treatment were enrolled after written consent. The patients underwent intervention treatment taking pegylated interferon $\alpha-2 b$ (Viraferon, Schering Plough Corp., Kenilworth, NJ) and ribavirin in accordance with the standard protocol. Patients were monitored through weekly referrals while taking the medications. A detailed history was taken and complete physical examination done each time the patient presented to the hospital necessary blood sampling was taken.

Results: During the study period of 2 years, 105 Patients were enrolled 55 $(52.4 \%)$ were males with a male:female ratio of $1.1: 1.0$. and mean age 37.6 years with a range of 13-75 years 7 patients (6.6) had a history of needle pricks, 4 patients $(2.2 \%)$ of sharing same razors at barber's shop. $4(3.8 \%)$ patients of drug abuse; out of which $3(2.8 \%)$ were intravenous drug abusers, Anemia occurred in $17(16.2 \%)$ patients with requirement of dose modification w in 11 $(10.4 \%)$ patients and dose stoppage in $1(0.95 \%)$ patient in whom $\mathrm{Hb}$ dropped to less than 7 , thrombocytopenia occurred in $27(25.7 \%)$ patients with requirement of dose modification in $13(12.3 \%)$ patients and dose stoppage in 1 $(0.95 \%)$ patients due to platelet count decreasing to less than 30,000 . Neutropenia as defined by ANC less than 1500 occurred in $22(20.9 \%)$ patients. Conclusions: Dose modification was required in $48(45.7 \%)$ patients, 30 $(28.5 \%)$ patients required dose modifications due to labortory abnormalities and $18(17.1 \%)$ due to other side effects. In $8(7.6 \%)$ patients dose was discontinued due to adverse events (including psychosis in 1, severe flu like symptoms in 3 , dermatitis in 1 , depression in 3 ).
\end{abstract}

Keywords: Hepatits C, Neuropsychiatric, Pegylated interferon $\alpha$-2b, Ribavirin

\section{INTRODUCTION}

Chronic hepatitis $\mathrm{C}$ infection is a very common disease globally affecting over 180 million people. It is a leading cause of chronic hepatitis, cirrhosis, and liver cancer and a primary indication for liver transplantation. The major types of side effects include fatigue, influenza-like symptoms, gastrointestinal disturbances, neuropsychiatric symptoms and hematologic abnormalities. ${ }^{1,2}$ These side effects may be treatment limiting and require dose reduction or drug discontinuation. ${ }^{3,4}$ Numerous other side effects occur with lower frequencies but may still have an impact on the tolerability of antiviral therapy. ${ }^{2}$ Pegylated interferons (peginterferon alfa-2a and peginterferon alfab) have significantly improved pharmacokinetics resulting in improved antiviral efficacy, which also has 
the potential to alter the side effect profile. ${ }^{5-8}$ Among the infrequently reported (1\%) prominent serious adverse events associated with standard interferon therapy are retinopathy, retinal hemorrhage, visual loss, tinnitus, hearing loss, cardiac arrhythmias, congestive heart failure, interstitial pneumonitis, acute renal failure, bacterial infections (particularly in patients with cirrhosis), and induction or exacerbation of autoimmune diseases, hyperthyroidism, hypothyroidism, acute psychosis, panic attacks, severe depression, and suicide. ${ }^{2,9-18}$

Certain adverse events associated with antiviral therapy have been responsible for most dose reductions and discontinuations and also have the greatest potential for altering the quality of life of individuals on antiviral therapy. Specific interventions may be available and deserve further discussion.

\section{Anemia}

Hemolytic anemia is a universal event associated with ribavirin combination therapy during therapy with standard interferon and ribavirin, hemoglobin levels decreased within the first 2-4 weeks of therapy with a mean maximal decrease of approximately $3 \mathrm{~g} / \mathrm{dl}$. $9 \%$ of participants treated with peginterferon and ribavirin required dose reductions due to decreased hemoglobin levels less than $10 \mathrm{~g} / \mathrm{dl} .^{7}$

Hemoglobin levels promptly return to normal once therapy is discontinued. Significant anemia associated with ribavirin therapy can increase fatigue, has a demonstrable effect on quality of life, and is a frequent indication for dose reduction of ribavirin. ${ }^{7,8,19}$

\section{Neutropenia}

Peginterferon induce neutropenia to a greater degree than standard interferons. Rapid decreases in neutrophil counts may be seen within the first 2 weeks of initiation of therapy and usually stabilize over the next 4 weeks as steady-state concentrations of peginterferon are achieved. Neutrophil counts rapidly return to baseline after therapy is discontinued. Recommendations for dose reduction of peginterferon alfa- $2 b$ at neutrophil counts of less than 750 cells $/ \mathrm{mm} .{ }^{20}$ Neutropenia is the most common reason for dose reduction of peginterferon and, thus, significantly interferes with adherence. ${ }^{7,8}$

\section{Thrombocytopenia}

Decreases in platelet counts also occur with therapy but have been infrequently associated with dose reduction or discontinuation. Rare instances of autoimmune thrombocytopenic purpura have been reported with peginterferon therapy, and marked decreases in platelet counts should be investigated for the role autoimmunity

\section{Depression}

Approximately $20 \%$ to $30 \%$ of patients treated with peginterferon and ribavirin report depression during therapy, making this a frequent cause of decreased quality of life and an indication for dose reduction and discontinuation. The relationship of depression and interferon therapy has recently been reviewed. ${ }^{21}$ In addition to depression, other manifestations such as irritability, anxiety, emotional lability, aggressive behaviors, mood disorders, and panic reactions have been reported. ${ }^{22}$ Evaluation of treatment-emergent side effects may be complicated by recently described subtle cognitive impairment before therapy pretreatment functional status and overlap with other side effects of interferon, such as fatigue and insomnia, which could exacerbate neuropsychiatric symptoms. ${ }^{23-27}$

Aims and objectives of the study was to assess the side effect profile of hepatitis $\mathrm{C}$ treatment (peginterferon alpha-2b and ribavarin) in Kashmiri patients attending the department of Gastroenterology, skims Soura.

\section{METHODS}

The present study was a prospective study conducted in the Department of Gastroenterology, Sher-i-Kashmir Institute of Medical Sciences, Srinagar, Kashmir, India. Our department is a referral center which receives patients from whole of the Kashmir. The study was carried from June 2013 to June 2015.

All consecutive patients of hepatitis $C$ infection who were on treatment on peginterferon and ribavarin were enrolled. Written informed consent was obtained from all patients. The patients underwent intervention treatment taking Pegylated interferon $\alpha-2 b$ (Viraferon, Schering Plough Corp., Kenilworth, NJ) and ribavirin in accordance with the standard protocol. This protocol consisted of $1.5 \mu \mathrm{g} / \mathrm{kilogram}$ of body weight of Pegylated interferon $\alpha-2 b$ administered subcutaneously once per week. In genotype 1 and 4 patients, who weighed less than $75 \mathrm{~kg}$, they were given ribavirin administered orally in $1000 \mathrm{mg}$ daily doses, and in patients who weighed over $75 \mathrm{~kg}$ the medication was administered orally in $1200 \mathrm{mg}$ daily doses. In genotype 2 and 3 patients, ribavirin was administered orally in $800 \mathrm{mg}$ daily doses.

The treatment length in genotype 1 and 4 patients was 48 weeks and it was 24 weeks in genotype 2 and 3 patients. Patients were monitored through weekly referrals while taking the medications. A detailed history was taken and complete physical examination done each time the patient presented to the hospital. Blood samples were drawn by venipuncture every week for first four weeks and then monthly till the completion of treatment. Blood samples were analysed for $\mathrm{Hb}$, TLC, DLC, ANC, Platelets. Thyroid profile was done at months $0,1,3$ and 6 . Mild to moderate complications were countered through a decrease in medication dosage or through the prescription 
of appropriate drugs. Lab criteria for dose reduction of peginterferon $\alpha-2 b$ included $500-750 / \mathrm{mm}^{3}$ neutrophils, $30000-50000 / \mathrm{mm} 3$ platelets or $\mathrm{Hb}$ less than $10 \mathrm{~g} / \mathrm{dl}$. Peginterferon- $\alpha$ was discontinued in cases of neutrophils less than $500 / \mathrm{mm} 3$, platelets less than $30000 / \mathrm{mm} 3$ and hemoglobin levels dropping below $7 \mathrm{~g} / \mathrm{dl}$. In addition, the ribavirin dosage was reduced in cases of hemoglobin levels falling below $10 \mathrm{~g} / \mathrm{dl}$ and it was stopped if hemoglobin dropped below $8.5 \mathrm{~g} / \mathrm{dl}$. G-CSF was prescribed when prolonged dose reduction was required because of neutropenia. Thrombopoeitin analogue eltrombopag $50 \mathrm{mg}$ was given when platelets dropped below $50,000 / \mathrm{mm}^{3}$.

\section{RESULTS}

During the study period of 2 years, 105 Patients were enrolled of which $55(52.4 \%)$ were males and $50(47.6 \%)$ were females with a male:female ratio of 1.1:1.0. The mean age was 37.6 years with a range of $13-75$ years. Majority of the patients were young (age <50yrs) $\mathrm{n}=88$ $(83.81 \%)$ while $17(16.19 \%)$ were older than 50.

About 34 patients (32.38\%) were smokers and 79 $(75.2 \%)$ had a previous history of dental instrumentation, about 7 patients $(6.6 \%)$ had a history of needle pricks. 4 patients $(2.2 \%)$ had a history of sharing same razors at barber's shop. $4(3.8 \%)$ patients had a history of drug abuse; out of which $3(2.8 \%)$ were intravenous drug abusers. Other risk factors were history of alcohol consumption ( $\mathrm{N}=6$ [5.7\%]); promiscuous sexual activity in form of multiple partners $(\mathrm{N}=2$ [1.9\%]); past history of surgery $(\mathrm{N}=39$ [37.1\%]) Majority of the patients $(83.8 \%)$ were in the age group of $<50$ years.

The general characteristics of these 105 patients of chronic hepatitis $\mathrm{C}$ are depicted in Table 1.

Table 1: The general characteristics of 105 patients of chronic hepatitis $\mathbf{C}$.

\begin{tabular}{|ll|}
\hline Parameters & Values \\
\hline Total cases & 105 \\
\hline Age, mean (range) in years & $37.6(13-75)$ years \\
\hline Sex, male: female & $55: 50$ \\
\hline Smoking & $34(32.38 \%)$ \\
\hline Dental extraction & $79(75.2 \%)$ \\
\hline Needle prick & $7(6.6 \%)$ \\
\hline Sharing razor & $4(2.2 \%)$ \\
\hline Sharing needles for injections & $3(2.8 \%)$ \\
\hline Blood products & $33(31.4 \%)$ \\
\hline Drug abuse & $4(3.8 \%)$ \\
\hline 'History of alcohol ingestion & $6(5.7 \%)$ \\
\hline Promiscuous sexual activity & $2(1.9 \%)$ \\
\hline Past surgery & $39(37.1 \%)$ \\
\hline
\end{tabular}

\section{Hematopoetic side effects}

\section{Anemia}

In our study group, anemia occurred in 17 (16.2\%) patients. The maximum drop in $\mathrm{Hb}$ occurred after 4 weeks with $\mathrm{Hb}$ dropped from a median of $13.5 \mathrm{~g} / \mathrm{dl}$ at baseline to $12.2 \mathrm{~g} / \mathrm{dl}$, there after remaining almost constant throughout treatment period.

Table 2: Frequency of side effects in $\mathbf{1 0 5}$ cases.

\begin{tabular}{|ll|}
\hline Adverse effect of treatment & \% affected $(\mathbf{n}=\mathbf{1 0 5})$ \\
\hline Fatigue & 66.6 \\
\hline Myalgias & 62.8 \\
\hline Headache & 60.9 \\
\hline Fever & 42.8 \\
\hline Insomnia & 38.1 \\
\hline Nausea & 34.3 \\
\hline Anorexia & 34.1 \\
\hline Pruritis & 26.6 \\
\hline Thrombocytopenia & 25.7 \\
\hline Alopecia & 24.7 \\
\hline Irritability & 24.7 \\
\hline Depression & 24.7 \\
\hline Psychosis & 1.9 \\
\hline Neutropenia & 20.9 \\
\hline Cough & 17.1 \\
\hline Diarrhea & 17.1 \\
\hline Dermatitis & 16.2 \\
\hline Anemia & 16.2 \\
\hline Hypothyroidism & 1.9 \\
\hline & \\
\hline & \\
\hline
\end{tabular}

Dose modification was required in $11(10.4 \%)$ patients in whom $\mathrm{Hb}$ dropped to less than $10 \mathrm{~g} / \mathrm{dl}$. Dose was stopped in $1(0.95 \%)$ patient in whom $\mathrm{Hb}$ dropped to less than 7.

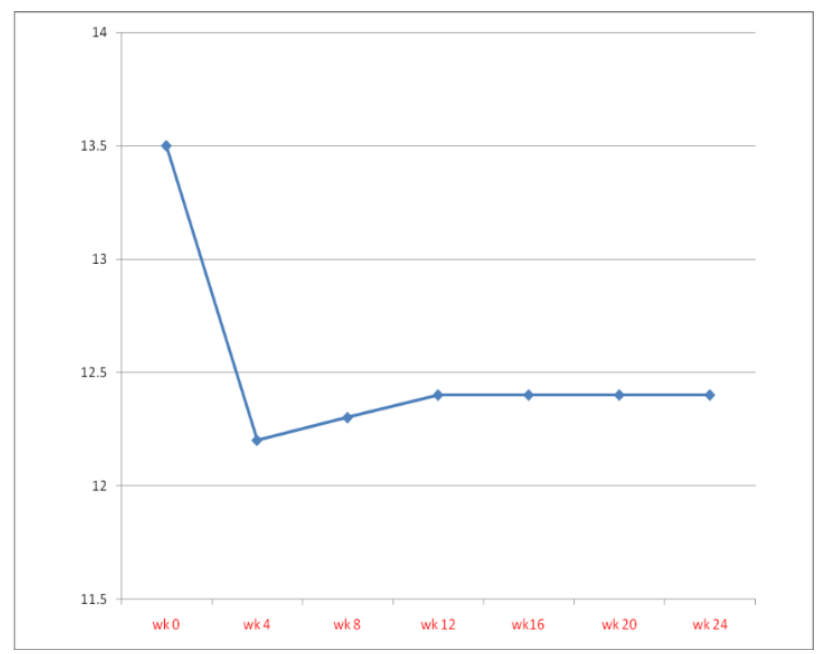

Figure 1: Change in median $\mathrm{Hb}$ during the 24 week course of peginterferon alpha- $2 b$ and ribavarin in 105 patients. 


\section{Thrombocytopenia}

In the 105 patients included in our study, thrombocytopenia occurred in $27(25.7 \%)$ patients. The maximum drop in platelets occurred in the first 4 weeks when median platelet count dropped from 1.35 lac to 1.11 lac and remained constant thereafter. Dose modification was required in $13(12.3 \%)$ patients due to platelet count dropping to less than 50,000. Dose was stopped in 1 $(0.95 \%)$ patients due to platelet count decreasing to less than 30,000. 10 of our patients received the thrombopoeitin analogue eltrombopeg for thrombocytopenia.

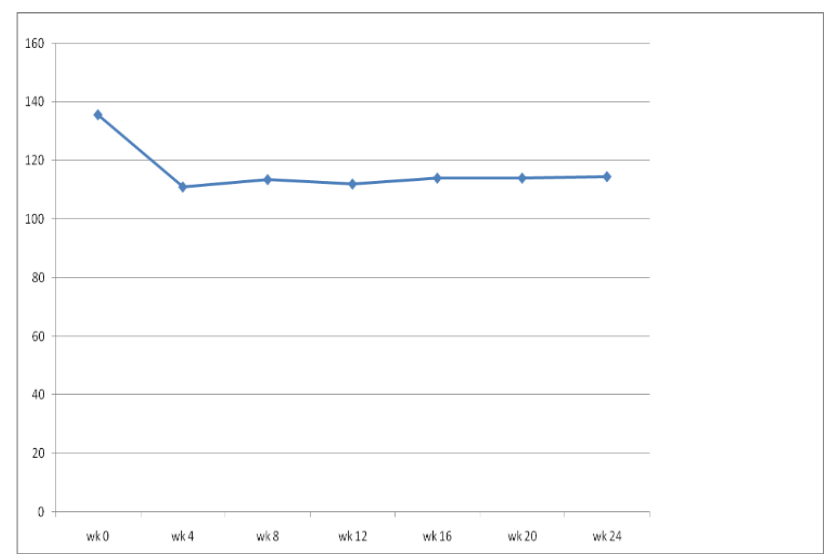

Figure 2: Change in median platelet count during a 24 week course of peginterferon alpha- $2 b$ and ribavirin.

\section{Neutropenia}

Neutropenia as defined by ANC less than 1500 occurred in $22(20.9 \%)$ patients in our study group. The maximum drop in leucocyte count occurred at the eighth week of therapy when median leucocyte count dropped to a value of 3300 from an initial value of $6400.14(13.3 \%)$ patients required dose modification due to neutropenia with ANC $<750$ and out of them $10(9.5 \%)$ patients received G-CSF. $2(1.9 \%)$ patients required discontinuation of therapy due to neutropenia (ANC<500).

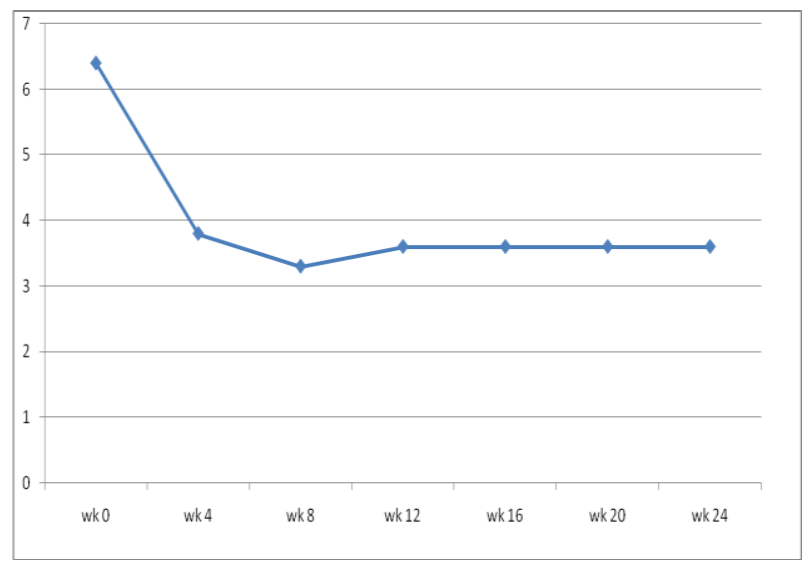

Figure 3: Line diagram showing change in median leucocyte count over a period of 24 weeks in 105 cases.

\section{Dose modifications during therapy}

Dose modification was required in a total of $48(45.7 \%)$ patients. $30(28.5 \%)$ patients required dose modifications due to labortory abnormalities and $18(17.1 \%)$ patients required dose modification for adverse events. The cause of modification was neutropenia only in $8(7.6 \%)$ patients, neutropenia plus thrombocytopenia in $5(4.7 \%)$ patients, neutropenia plus anemia in $1(0.95 \%)$ patient, anemia only in $8(7.6 \%)$ patients, anemia plus thrombocytopenia in $2(1.9 \%)$ patients and thrombocytopenia only in $6(5.71 \%)$ patients. Thus out of all 30 patients who required dose modification due to labortory abnormalties, neutropenia was present in 14 $(13.3 \%)$ patients, anemia in $11(10.4 \%)$ and thrombocytopenia in $13(12.38 \%)$ patients. Of the adverse events requiring dose modification 9 patients had severe flu like symptoms,3 had dermatitis, 2 had diarrhea, 3 had depression and 1 had pruritis.

\section{Dose discontinuation during therapy}

Of all the 105 patients included in our study, dose discontinuation was required in $13(12.3 \%)$ patients. Of these $1(0.95 \%)$ had thrombocytopenia, $1(0.95 \%)$ had anemia, $2(1.9 \%)$ had neutropenia, 1 had hypothyroidism and in $8(7.6 \%)$ patients dose was discontinued due to adverse events (including psychosis in 1, severe flu like symptoms in 3 , dermatitis in 1 , depression in 3 ).

Table 3: Various factors causing dose discontinuation in our study.

\begin{tabular}{|ll|}
\hline Abnormality & Number $(\%)$ \\
\hline Adverse event & $8(7.6 \%)$ \\
\hline Anemia & $1(0.95 \%)$ \\
\hline Thrombocytopenia & $1(0.95 \%)$ \\
\hline Neutropenia & $2(1.9 \%)$ \\
\hline Hypothyroidism & $1(0.95 \%)$ \\
\hline
\end{tabular}

\section{DISCUSSION}

The present study was conceived to assess the side effect profile of hepatitis $\mathrm{c}$ treatment in kashmiri patients on antiviral therapy with a combination of pegylated interferon-alfa $2 b$ and ribavirin.During this study period due to the non availability of oral antivirals in India, standard of care (SOC) for all HCV genotypes continued to be antiviral therapy consisting of combination of pegylated interferon alfa $2 \mathrm{a}$ or $2 \mathrm{~b}$ and ribavirin (Peg-IFNa/R) for 24 weeks for genotypes 2 and 3 or 48 weeks for genotypes 1 .In our study Amongst the various adverse events observed fatigue was most common $(n=70 ; 66.6 \%)$ followed by myalgias $(n=66 ; 62.8 \%)$, headache $(n=64 ; 60.9 \%), \quad$ fever $\quad(n=45 ; 42.8 \%), \quad$ insomnia $(n=40 ; 38.1 \%), \quad$ nausea $\quad(n=36 ; 34.3 \%), \quad$ anorexia $(\mathrm{n}=35 ; 34.1 \%), \quad$ pruritic $\quad(\mathrm{n}=28 ; 26.6 \%), \quad$ alopecia $(\mathrm{n}=26 ; 24.7 \%), \quad$ Irritability $\quad(\mathrm{n}=26 ; 24.7) \quad$ depression $(n=26: 24.7)$, cough $(18 ; 17.1 \%)$, diarrhea $(n=18 ; 17.1 \%)$, 
dyspnea $(n=17 ; 16.2 \%)$, dermatitis $(17 ; 16.2 \%)$. Manns et al, reported fatigue in $60 \%$, headache in $58 \%$, fever in $33 \%$, myalgias in $50 \%$, insomnia in $41 \%$, nausea in $41 \%$, alopecia in $32 \%$, irritability in $34 \%$, arthralgias in $28 \%$, depression in $34 \%$ and dermatitis in $36 \%$. $^{7}$

Table 4: Comparison of various studies with our study.

\begin{tabular}{|c|c|c|c|c|}
\hline $\begin{array}{l}\text { Study } \\
\text { (Author } \\
\text { and year) }\end{array}$ & Country & Males & Females & $\begin{array}{l}\text { Mean } \\
\text { Age }\end{array}$ \\
\hline Our study & India & $\begin{array}{l}55 \\
(52.4 \%)\end{array}$ & $\begin{array}{l}50 \\
(47.6 \%)\end{array}$ & $\begin{array}{l}37.6 \\
(13-75)\end{array}$ \\
\hline $\begin{array}{l}\text { Hazari et } \\
\mathrm{al}^{28}\end{array}$ & India & $\begin{array}{l}45 \\
(69.2 \%)\end{array}$ & $\begin{array}{l}20 \\
(30.8 \%)\end{array}$ & $\begin{array}{c}39 \pm 12 \\
(22-64)\end{array}$ \\
\hline $\begin{array}{l}\text { Hissar et } \\
\mathrm{al}^{29}\end{array}$ & India & $\begin{array}{l}279 \\
(70.1 \%)\end{array}$ & $\begin{array}{l}119 \\
(29.9 \%)\end{array}$ & $\begin{array}{l}41 \pm 13.5 \\
(2-88)\end{array}$ \\
\hline Davis et al ${ }^{30}$ & $\begin{array}{l}\text { USA and } \\
\text { Germany }\end{array}$ & $\begin{array}{l}723 \\
(60 \%)\end{array}$ & $\begin{array}{l}481 \\
(40 \%)\end{array}$ & $42.8 \pm 8.7$ \\
\hline Yu et $\mathrm{al}^{31}$ & China & $\begin{array}{l}56 \\
(53.3 \%)\end{array}$ & $\begin{array}{l}49 \\
(46.7 \%)\end{array}$ & $41 \pm 7$ \\
\hline $\begin{array}{l}\text { Kuboki et } \\
\mathrm{al}^{32}\end{array}$ & Japan & $\begin{array}{l}198 \\
(66 \%)\end{array}$ & $\begin{array}{l}102 \\
(34 \%)\end{array}$ & 51.5 \\
\hline Kim et $\mathrm{al}^{33}$ & S. Korea & $\begin{array}{l}33 \\
(51.5 \%)\end{array}$ & $\begin{array}{l}31 \\
(49.5 \%)\end{array}$ & $50.1 \pm 9.8$ \\
\hline $\begin{array}{l}\text { Alfaleh et } \\
\mathrm{al}^{34}\end{array}$ & $\begin{array}{l}\text { Saudi } \\
\text { Arabia }\end{array}$ & $\begin{array}{l}54 \\
(56.2 \%)\end{array}$ & $\begin{array}{l}42 \\
(43.8 \%)\end{array}$ & $47.4 \pm 10.4$ \\
\hline $\begin{array}{l}\text { Borroni et } \\
\mathrm{al}^{35}\end{array}$ & Italy & $\begin{array}{l}230 \\
(58 \%)\end{array}$ & $\begin{array}{l}167 \\
(42 \%)\end{array}$ & $\begin{array}{l}47.7 \pm 12.7 \\
(18-70)\end{array}$ \\
\hline 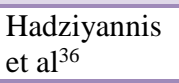 & $\begin{array}{l}\text { Multicentre } \\
\text { European }\end{array}$ & $\begin{array}{l}288 \\
(66 \%)\end{array}$ & $\begin{array}{l}148 \\
(34 \%)\end{array}$ & $43 \pm 10.1$ \\
\hline Fried et $\mathrm{al}^{8}$ & $\begin{array}{l}\text { Multicentre } \\
\text { European }\end{array}$ & $\begin{array}{l}326 \\
(72 \%)\end{array}$ & $\begin{array}{l}127 \\
(28 \%)\end{array}$ & $48.2 \pm 10.1$ \\
\hline Manns et al ${ }^{7}$ & $\begin{array}{l}\text { Multicentre } \\
\text { European }\end{array}$ & $\begin{array}{l}322 \\
(63 \%)\end{array}$ & $\begin{array}{l}189 \\
(37 \%)\end{array}$ & 43 \\
\hline
\end{tabular}

Hematopoietic side effects; In our study group, anemia occurred in $17(16.2 \%)$ patients. Dose modification was required in $11(10.4 \%)$ patients This is consistent with previous studies done in other parts of the world. Manns et al reported that a decrease in haemoglobin to less than $100 \mathrm{~g} / \mathrm{L}$, the protocol requirement for dose modification occurred in $9 \%$ of patients. ${ }^{7}$ Stefan Zeuzem Maria Buti, reported a decrease in hemoglobin to less than $10 \mathrm{~g} / \mathrm{dl}$ in $12 \%$ patients Montserrat Laguno, Javier Murillas et al, reported that a decrease in haemoglobin to, $100 \mathrm{~g} / \mathrm{l}$, the protocol requirement for dose modification, occurred in $13 \%$ of patients and discontinuation for anaemia was rare (one patient). ${ }^{37}$ The maximum drop in $\mathrm{Hb}$ occurred after 4 weeks of treatment when $\mathrm{Hb}$ dropped from a median of $13.5 \mathrm{~g} / \mathrm{dl}$ at baseline to $12.2 \mathrm{~g} / \mathrm{dl}$, there after remaining almost constant throughout treatment period. In previous other studies the maximum drop in average hemoglobin has been more but like in our study average $\mathrm{Hb}$ stabilised after first few weeks of treatment. Manns et al, reported a maximum drop in $\mathrm{Hb}$ of $2.5 \mathrm{~g} / \mathrm{dl}$ after first $4-8$ weeks of treatment and remained constant thereafter. ${ }^{7}$ M. S. Sulkowski, R. Wasserman et al, reported a maximum drop in average $\mathrm{Hb}$ of $2 \mathrm{mg} / \mathrm{dl}$ occurring after 4 weeks of treatment. ${ }^{38}$ The lower absolute drop in average $\mathrm{Hb}$ in our study group may be explained by lower value of $\mathrm{Hb}$ at baseline as also found by M. S. Sulkowski. ${ }^{38}$

\section{Thrombocytopenia}

In our study of 105 patients thrombocytopenia occurred in $27(25.7 \%)$ patients. Dose modification was required in $13(12.3 \%)$ patients due to platelet count dropping to less than 50,000 and stopped in $1(0.95 \%)$ patients due to platelet count decreasing to less than 30,000. Thrombocytopenia and dose modification due to thrombocytopenia was higher than reported previously. MANNS et al reported that $3 \%$ of patients had a platelet decrease that reached the protocol defined criterion for dose reduction. No patient discontinued therapy owing to thrombocytopenia M. S. Sulkowski, R. Wasserman et al reported thrombocytopenia in $8 \%$ patients with $2 \%$ requiring dose modification and $<1 \%$ requiring dose discontinuation due to thrombocytopenia Antonio Ascione et al. reported dose modification due to thrombocytopenia in 3\% patients Robert Roomer, Bettina E. Hansen et al, reported dose modification in $3.7 \%$ patients due to thrombocytopenia on peginterferon alpha$2 \mathrm{~b}$ and ribavarin treatments. ${ }^{7,38-40}$ The maximum drop in platelets occurred in the first 4 weeks of treatment. This was consistent with previous studies. M Schmid et al reported a maximum drop in platelets after 4 weeks which remained constant thereafter. Karen L et al, reported that platelet counts decreased from baseline during the first few weeks of treatment and stabilized during the remainder of treatment. ${ }^{41}$ Neutropenia:Neutropenia as defined by ANC less than 1500 occurred in $22(20.9 \%)$ patients in our study group. $14(13.3 \%)$ patients required dose modification due to neutropenia with ANC $<750$ and 2 (1.9\%) patients required discontinuation of therapy due to neutropenia $(\mathrm{ANC}<500)$. This is consistent with studies done previously. Manns et al, reported that the frequency of dose reduction for neutropenia was $18 \%$ for the peginterferon alfa- $2 \mathrm{~b}$ plus ribavirin regimen and $1 \%$ or less of patients discontinued treatment for neutropenia. ${ }^{7}$ Their ypoynard et al, reported neutropenia in $20 \%$ patients with $8 \%$ requiring dose modifications because of neutropenia. Andrew J et al, reported dose modification due to neutropenia in $14 \%$ patients and 3\%patients requiring dose discontinuation due to neutropenia. ${ }^{42}$ In our study the maximum drop in median neutrophill count occurred after 8 weeks of therapy remaining constant thereafter till the completion of treatment. Similar findings have been made previously. M Schmid, et al reported a maximum drop in neutrophill count after 8 weeks of treatment after which it stabilised Andrew J. et al noticed a maximum drop in ANC after 4 weeks of treatment, stabilizing around this value thereafter. ${ }^{43}$ Neuropsychiatric side effects: Out of all the neuropsychiatric side effects depression was reported by $24.7 \%$ patients and equal number of patients $(24.7 \%)$ developed irritability. Similar findings have been made previously by Michael P Manns, John G mchutchison who reported depression in $31 \%$ patients and irritability 
in $35 \%$ patients. $^{7} 2(1.9 \%)$ patient developed psychosis on treatment and treatment was discontinued because of psychosis in 1. Nasir khokar reported psychosis in $2 \%$ patients on peginterferon alpha- $2 \mathrm{~b}$ and ribavarin treatment. Endocrine EFFECTS: 2 (1.9\%) patients developed hypothyroidism while on treatment with peginterferon alpha- $2 b$ and ribavarin. None of our patients developed hyperthyroidism. Thyroid dysfunctions (both hypothyroidism and hyperthyroidism) have been reported previously also. Edmund J. Bini, Saurabh et al, reported hypothyroidism in $5.3 \%$ patients Dose modifications and dose discontinuation: Dose modification was required in a total of $45.7 \%$ patients. $28.5 \%$ patients required dose modifications due to labortory abnormalities and $17.1 \%$ patients required dose modification for adverse events. Manns et al have previously reported a higher frequency of dose modification for adverse events (42\%). ${ }^{7}$ Of the patients who required dose modification due to labortory abnormalties, neutropenia was present in $13.3 \%$ patients, anemia in $10.4 \%$ and thrombocytopenia in $12.38 \%$ patients. Number of patients requiring dose modification for thrombocytopenia was higher in our study than previously reported. Patients requiring dose modification for anemia and neutropenia was the same as reported previously. Manns et al reported $18 \%$ patients required dose modification for neutropenia and $9 \%$ required dose modification for anemia. ${ }^{7}$

\section{CONCLUSION}

Of all the 105 patients included in our study, dose discontinuation was required in $13(12.3 \%)$ patients. Of these $1(0.95 \%)$ had thrombocytopenia,1(0.95\%)had anemia, $2(1.9 \%)$ had neutropenia, 1 had hypothyroidism and in $8(7.6 \%)$ patients dose was discontinued due to adverse events (including psychosis in 1, severe flu like symptoms in 3, dermatitis in 1, depression in 3). Thus, of all the adverse events requiring dose discontinuation, neuropsychiatric symptoms accounted for the majority. Neuropsychiatric side effects were the most common adverse events requiring dose discontinuation (3.8\%). Neutropenia was the most common lab. abnormality requiring dose discontinuation $[n=2(1.9 \%)]$.

\section{Funding: No funding sources} Conflict of interest: None declared

Ethical approval: The study was approved by the Institutional Ethics Committee

\section{REFERENCES}

1. Afdhal NH, Geahigan T. Supporting the patient with chronic hepatitis during treatment. InChronic Viral Hepatitis. Humana Press; 2002:211-232.

2. Maddrey WC. Safety of combination interferon alfa$2 \mathrm{~b}$ /ribavirin therapy in chronic hepatitis C-relapsed and treatment-naive patients. InSeminars in liver disease. 1998 Dec;19:67-75.
3. McHutchison JG, Poynard T. Combination therapy with interferon plus ribavirin for the initial treatment of chronic hepatitis C. In Seminars in liver disease. 1998 Dec;19:57-65.

4. Poynard T, Marcellin P, Lee SS, Niederau C, Minuk $\mathrm{GS}$, Ideo $\mathrm{G}$, et al. Randomised trial of interferon $\alpha 2 \mathrm{~b}$ plus ribavirin for 48 weeks or for 24 weeks versus interferon $\alpha 2 b$ plus placebo for 48 weeks for treatment of chronic infection with hepatitis $\mathrm{C}$ virus. The Lancet. 1998 Oct 31;352(9138):1426-32.

5. Glue P, Fang JW, Rouzier-Panis R, Raffanel C, Sabo R, Gupta SK, et al. Pegylated interferon- $\alpha 2 b$ : Pharmacokinetics, pharmacodynamics, safety, and preliminary efficacy data. Clinical Pharmacology and Therapeutics. 2000 Nov 1;68(5):556-67.

6. Modi M, Martin N, Heathcote JE, Nieforth K, Zeuzem S. Peginterferon alfa-2a $(40 \mathrm{kDa})$ monotherapy: a novel agent for chronic hepatitis $\mathrm{C}$ therapy. Expert opinion on investigational drugs. 2001 Dec 1;10(12):2201-13.

7. Manns MP, McHutchison JG, Gordon SC, Rustgi VK, Shiffman M, Reindollar R, et al. International Hepatitis Interventional Therapy Group. Peginterferon alfa-2b plus ribavirin compared with interferon alfa-2b plus ribavirin for initial treatment of chronic hepatitis $\mathrm{C}$ : a randomised trial. The Lancet. 2001 Sep 22;358(9286):958-65.

8. Fried MW, Shiffman ML, Reddy KR, Smith C, Marinos G, Gonçales Jr FL, et al. Peginterferon alfa2a plus ribavirin for chronic hepatitis $\mathrm{C}$ virus infection. New England Journal of Medicine. 2002 Sep 26;347(13):975-82.

9. Jain K, Lam WC, Waheeb S, Thai Q, Heathcote J. Retinopathy in chronic hepatitis $\mathrm{C}$ patients during interferon treatment with ribavirin. British journal of ophthalmology. 2001 Oct 1;85(10):1171-3.

10. Hejny C, Paul S, Lawson DH, Greiner K. Retinopathy associated with high-dose interferon alfa-2b therapy American Journal of Ophthalmology. June 2001;131(6):782-7.

11. Nadir A, Amin A, Chalisa N, Van Thiel DH. Retinal vein thrombosis associated with chronic hepatitis $C$ : a case series and review of the literature. Journal of viral hepatitis. 2000 Nov 1;7(6):466-70.

12. Cadoni G, Marinelli L, De Santis A, Romito A, Manna R, Ottaviani F. Sudden hearing loss in a patient hepatitis $\mathrm{C}$ virus (HCV) positive on therapy with alpha-interferon: a possible autoimmunemicrovascular pathogenesis. The Journal of Laryngology and Otology. 1998 Oct 1;112(10):9623.

13. Karim A, Ahmed S, Khan A, Steinberg H, Mattana J. Interstitial pneumonitis in a patient treated with $\alpha$ interferon and ribavirin for hepatitis $\mathrm{C}$ infection. The American journal of the medical sciences. 2001 Oct 31;322(4):233-5.

14. Chin K, Tabata C, Sataka N, Nagai S, Moriyasu F, Kuno K. Pneumonitis associated with natural and recombinant interferon alfa therapy for chronic 
hepatitis C. CHEST Journal. 1994 Mar;105(3):93941.

15. Boonyapisit K, Katirji B. Severe exacerbation of hepatitis C-associated vasculitic neuropathy following treatment with interferon alpha: a case report and literature review. Muscle \& nerve. 2002 Jun;25(6):909-13.

16. Li SD, Yong S, Srinivas D, Van Thiel DH. Reactivation of sarcoidosis during interferon therapy. Journal of gastroenterology. 2002 Jan 20;37(1):50-4.

17. Teragawa H, Hondo T, Amano H, Hino F, Ohbayashi M. Adverse effects of interferon on the cardiovascular system in patients with chronic hepatitis C. Japanese heart journal. 1996;37(6):90515.

18. Fujiwara T, Kiura K, Ochi $\mathrm{K}$, Matsubara $\mathrm{H}$, Yamanari $\mathrm{H}$, Shimomura $\mathrm{H}$, et al. Giant negative $\mathrm{T}$ waves during interferon therapy in a patient with chronic hepatitis $C$. Internal Medicine. 2001;40(2):105-9.

19. Neary MP, Cort S, Bayliss MS, Ware Jr JE. Sustained virologic response is associated with improved health-related quality of life in relapsed chronic hepatitis $\mathrm{C}$ patients. In Seminars in liver disease. 1998 Dec;19:77-85.

20. Schering corporation 20000 galloping hill road Kenilworth nj07033 department of health and human service. Public health service division of antiviral drugs products food and drug administration Rockville MD 20857 Dosage and administration. Package insert 2002 NDA 20-903/S-023.

21. Trask PC, Esper P, Riba M, Redman B. Psychiatric side effects of interferon therapy: prevalence, proposed mechanisms, and future directions. Journal of Clinical Oncology. 2000 Jun 11;18(11):2316-26.

22. Fontana R. Neuropsychiatric toxicity of antiviral treatment in chronic hepatitis C. Digestive Diseases. 2000;18(3):107-16.

23. Forton DM, Thomas HC, Murphy CA, Allsop JM, Foster GR, Main J, et al. Hepatitis C and cognitive impairment in a cohort of patients with mild liver disease. Hepatology. 2002 Feb 1;35(2):433-9.

24. Hilsabeck RC, Perry W, Hassanein TI. Neuropsychological impairment in patients with chronic hepatitis C. Hepatology. 2002 Feb 1;35(2):440-6.

25. Dwight MM, Kowdley KV, Russo JE, Ciechanowski PS, Larson AM, Katon WJ. Depression, fatigue, and functional disability in patients with chronic hepatitis C. Journal of psychosomatic research. $2000 \mathrm{Nov}$ 30;49(5):311-7.

26. Kraus MR, Schãfer A, Csef H, Faller H, Mõrk H, Scheurlen M. Compliance with therapy in patients with chronic hepatitis $\mathrm{C}$ : associations with psychiatric symptoms, interpersonal problems, and mode of acquisition. Digestive diseases and sciences. 2001 Oct 1;46(10):2060-5.

27. Poynard T, Cacoub P, Ratziu V, Myers RP, Dezailles $\mathrm{MH}$, Mercadier A, et al. Fatigue in patients with chronic hepatitis C. Journal of viral hepatitis. 2002 Jul 1;9(4):295-303.

28. Hazari S, Panda SK, Gupta SD, Batra Y, Singh R, Acharya SK. Treatment of hepatitis $C$ virus infection in patients of northern India. Journal of gastroenterology and hepatology. 2004 Sep;19(9):1058-65.

29. Hissar SS, Goyal A, Kumar M, Pandey C, Suneetha PV, Sood A, et al. Hepatitis C virus genotype 3 predominates in North and Central India and is associated with significant histopathologic liver disease. Journal of medical virology. 2006 Apr;78(4):452-8.

30. Davis GL, Wong JB, McHutchison JG, Manns MP, Harvey J, Albrecht J. Early virologic response to treatment with peginterferon alfa- $2 b$ plus ribavirin in patients with chronic hepatitis C. Hepatology. 2003 Sep 1;38(3):645-52.

31. Yu JW, Wang GQ, Sun LJ, Li XG, Li SC. Predictive value of rapid virological response and early virological response on sustained virological response in $\mathrm{HCV}$ patients treated with pegylated interferon $\alpha-2 \mathrm{a}$ and ribavirin. Journal of gastroenterology and hepatology. 2007 Jun;22(6):832-6.

32. Kuboki M, Iino S, Okuno T, Omata M, Kiyosawa K, Kumada H, et al. Peginterferon $\alpha$-2a $(40 \mathrm{KD})$ plus ribavirin for the treatment of chronic hepatitis $\mathrm{C}$ in Japanese patients. Journal of Gastroenterology and Hepatology. 2007 May ;22(5):645-52.

33. Kim KT, Han SY, Kim JH, Yoon HA, Baek YH, Kim MJ, et al. Clinical outcome of pegylated interferon and ribavirin therapy for chronic hepatitis C. The Korean journal of hepatology. 2008 Mar;14(1):36-45.

34. Alfaleh FZ, Hadad Q, Khuroo MS, Aljumah A, Algamedi A, Alashgar $\mathrm{H}$, et al. Peginterferon $\alpha-2 b$ plus ribavirin compared with interferon $\alpha-2 b$ plus ribavirin for initial treatment of chronic hepatitis $\mathrm{C}$ in Saudi patients commonly infected with genotype 4 . Liver International. 2004 Dec ;24(6):568-74.

35. Borroni G, Andreoletti M, Casiraghi MA, Ceriani R, Guerzoni P, Omazzi B, et al. Effectiveness of pegylated interferon/ribavirin combination in 'real world'patients with chronic hepatitis $\mathrm{C}$ virus infection. Alimentary pharmacology \& therapeutics. 2008 May ;27(9):790-7.

36. Hadziyannis SJ, Sette H, Morgan TR, Balan V, Diago M, Marcellin P, et al. Peginterferon- $\alpha 2 \mathrm{a}$ and ribavirin combination therapy in chronic hepatitis ca randomized study of treatment duration and ribavirin dose. Annals of internal medicine. 2004 Mar;140(5):346-55.

37. Zeuzem S, Buti M, Ferenci P, Sperl J, Horsmans Y, Cianciara $\mathrm{J}$, et al. Efficacy of 24 weeks treatment with peginterferon alfa-2b plus ribavirin in patients with chronic hepatitis $\mathrm{C}$ infected with genotype 1 and low pretreatment viremia. Journal of hepatology. 2006 Jan;44(1):97-103. 
38. Sulkowski MS, Wasserman R, Brooks L, Ball L, Gish R. Changes in haemoglobin during interferon alpha-2b plus ribavirin combination therapy for chronic hepatitis $\mathrm{C}$ virus infection. Journal of viral hepatitis. 2004 May;11(3):243-50.

39. Ascione A, De Luca M, Tartaglione MT, Lampasi F, Di Costanzo GG, Lanza AG, et al. Peginterferon alfa2 a plus ribavirin is more effective than peginterferon alfa-2b plus ribavirin for treating chronic hepatitis $\mathrm{C}$ virus infection. Gastroenterology. 2010 Jan;138(1):116-22.

40. Roomer R, Hansen BE, Janssen HL, de Knegt RJ. Risk factors for infection during treatment with peginterferon alfa and ribavirin for chronic hepatitis C. Hepatology. 2010 Oct 1;52(4):1225-31.

41. Lindsay KL, Trepo C, Heintges T, Shiffman ML, Gordon SC, Hoefs JC, et al. A randomized, double- blind trial comparing pegylated interferon alfa- $2 b$ to interferon alfa- $2 b$ as initial treatment for chronic hepatitis C. Hepatology. 2001 Aug;34(2):395-403.

42. Farci P, Mandas A, Coiana A, Lai ME, Desmet V, Van Eyken P, et al. Treatment of chronic hepatitis D with interferon alfa-2a. New England Journal of Medicine. 1994 Jan 13;330(2):88-94.

43. Muir AJ, MHS, Bornstein JD, Paul G. Peginterferon Alfa-2b and Ribavirin for the Treatment of Chronic Hepatitis C in Blacks and Non-Hispanic Whites N Engl J Med. 2004 May;350:2265-71.

Cite this article as: Syed M, Gul I, Rasool A, Gul S, Gulzar GM, Wani MA. Side effect profile of hepatitis $\mathrm{C}$ treatment with peginterferon alpha-2b and ribavarin. Int J Basic Clin Pharmacol 2017;6:157784. 